\title{
Articulo original / Original Article \\ Sideritis perfoliata inhibits cell proliferation, induces apoptosis and exhibits cellular antioxidant activity in cervical cancer cells
}

\author{
[Sideritis perfoliata inhibe la proliferación celular, induce apoptosis y exhibe actividad antioxidante celular en \\ células de cáncer de cuello uterino]
}

\author{
Gizem Cocelli ${ }^{1}$, Mustafa Pehlivan ${ }^{2} \&$ Onder Yumrutas ${ }^{3}$ \\ ${ }^{1}$ Department of Biology, Faculty of Science, University of Gaziantep, Gaziantep, Turkey \\ ${ }^{2}$ Department of Medicinal and Aromatic Plants, Nurdağ1 Vocational High School, University of Gaziantep, Gaziantep, Turkey \\ ${ }^{3}$ Department of Medical Biology, Faculty of Medicine, University of Adıyaman, Adıyaman, Turkey
}

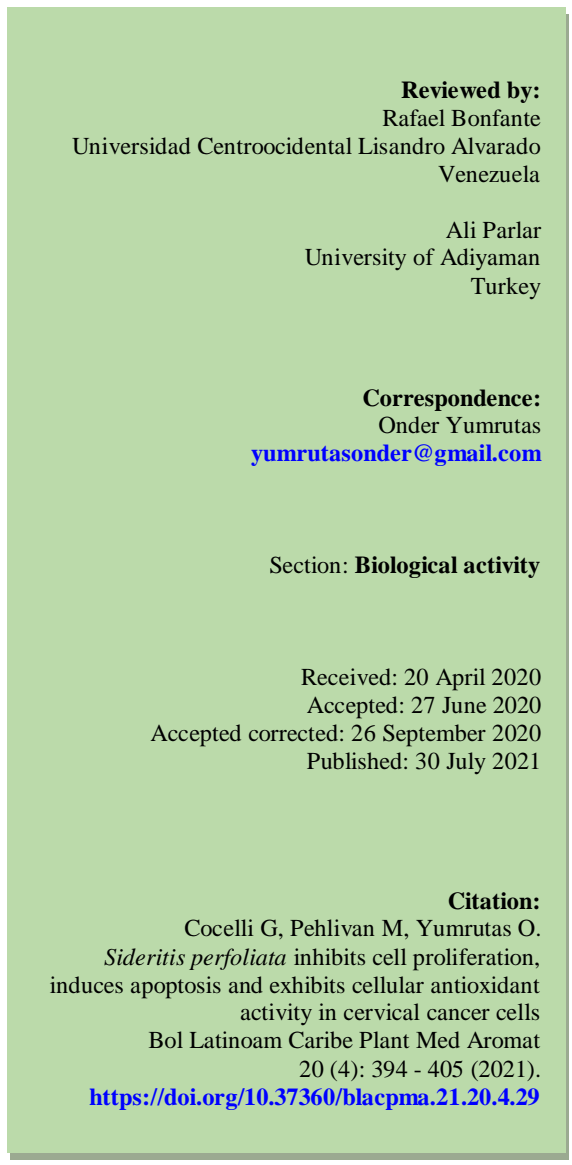

Abstract: In this study, it was aimed to determine the antioxidant and anticancer activities of Sideritis perfoliata methanolic extract (SPE) on cervical cancer cells (HeLa). Different doses (25, 50, 100 and 200 $\mu \mathrm{g} / \mathrm{mL}$ ) of SPE were used to determine proliferation of HeLa cells by 3-[4,5-dimethylthiazol-2-yl]-2,5diphenyl-tetrazolium bromide (MTT) staining method. Induction of apoptosis was determined by Annexine-V and propidium iodide staining method. Interleukin (IL) 6-8 levels were measured by ELISA method. Antioxidant activities of SPE were determined by DPPH, DNA (plasmid pBR322) protecting and cellular antioxidant activity tests. Some phytochemicals of SPE were also screened by LC-MS-MS. It was determined that SPE reduced the proliferation of HeLa cells and also induced apoptosis. IL6-8 levels importantly decreased at $200 \mu \mathrm{g} / \mathrm{mL}$. SPE exhibited moderately antioxidant activities in tests used. Among the phenolics identified, vanillic acid had the highest amount. As a result, it was determined to have the anticancer activity of SPE by decreasing cell proliferation, inducing apoptosis and decreasing IL6-8 in HeLa cells.

Keywords: Anticancer; Apoptosis; Cellular antioxidant activity; Interleukin 6 and 8; Cervical cancer; Sideritis perfoliata

Resumen: En este estudio, se tuvo como objetivo determinar las actividades antioxidantes y anticancerígenas del extracto metanólico de Sideritis perfoliata (SPE) en las células de cáncer de cuello uterino (HeLa). Se utilizaron diferentes dosis $(25,50,100$ y $200 \mu \mathrm{g} / \mathrm{mL})$ de SPE para determinar la proliferación de células HeLa mediante el método de tinción con bromuro de 3- [4,5-dimetiltiazol-2-il] 2,5-difenil-tetrazolio (MTT). La inducción de apoptosis se determinó mediante el método de tinción con anexina-V y yoduro de propidio. Los niveles de interleucina (IL) 6-8 se midieron mediante el método ELISA. Las actividades antioxidantes de SPE se determinaron mediante pruebas de DPPH, protección de ADN (plásmido pBR322) y actividad antioxidante celular. Algunos fitoquímicos de SPE también se analizaron mediante LC-MS-MS. Se determinó que SPE redujo la proliferación de células HeLa y también indujo apoptosis. Los niveles de IL6-8 disminuyeron de manera importante a $200 \mu \mathrm{g} / \mathrm{mL}$. SPE mostró actividades moderadamente antioxidantes en las pruebas utilizadas. Entre los fenólicos identificados, el ácido vainílico tuvo la mayor cantidad. Como resultado, se determinó que tenía la actividad anticancerígena de SPE al disminuir la proliferación celular, inducir apoptosis y disminuir la IL6-8 en las células HeLa.

Palabras clave: Anticancerígeno; Apoptosis; Actividad antioxidante celular; Interleucina 6 y 8; Cáncer de cuello uterino; Sideritis perfoliata. 


\section{INTRODUCTION}

Cancer is the one of diseases to have a rate of highmortality. Lung, prostate, colorectal, stomach and liver cancers in men are the most common, while breast, colorectal, lung, cervical and thyroid cancer are the most common in women (WHO, 2018). Cervical cancer is cause to $7.5 \%$ of deaths caused by cancer in women (Bray et al., 2018). The factors including virus infection (Smith et al., 2002), expression of oncogenes (Mammas et al., 2004), overexpression of proinflammatory cytokines such as IL6 and IL8 (Tjiong et al., 1999; Waugh \& Wilson, 2008) associated with cervical cancer.

There are a few different methodological approaches to treatment of cancer, and the cancer treatment with synthetic or natural agents is among these methods used. In these agents it is sought many features such as reducing of the viability and proliferation of cancer cells, inducting of apoptosis, blocking the cell cycle and suppression of the oncogene products (Pavithra et al., 2018; Kim et al. 2018). Many of plant-based chemicals, which were discovered as anti-cancer agents and their derivatives, have been used in preclinical tests so far (Ijaz et al., 2018). In parallel with increasing cancer cases, the discovery of new natural agents have been gained importance to treatment them. Especially, plants belonging to Lamiaceae are used as important sources for this purpose (Pudziuvelyte et al., 2017; Shakeri et al., 2019; Balusamy et al., 2018). Many phytochemical agents in this genus are used in the treatment of many diseases, including cancer for a long time.

Lamiaceae, which are represented by about 245 genera and 7886 species in the world (Celep \& Dirmenci, 2017) and is represented by 45 genera and 558 species, 247 of which are endemic in Turkey (Davis et al., 1988; Guner et al., 2000). Sideritis genus belonging to Lamiaceae is represented by more than 150 species (Ramos et al., 1994). It has been determined that Sideritis species contain many seconder components such as terpenes, flavonoids, volatile oil, iridoids, coumarins, lignans and sterols. More than 160 diterpenes have been identified in Sideritis species which are rich in flavonoid content and isolated from aerial parts (Gonzalez-Burgos et al., 2011).

Sideritis species have been used due to their medicinal properties including anti-inflammatory (Küpeli et al., 2007), antimicrobial (Köse et al., 2010), antioxidant (Erkan et al., 2011), anticholinesterase (Ertaş et al., 2009), and analgesic
(Hernández-Pérez \& Rabanal Gallego, 2002) for a long time. In the present study, it was aim to determine the anticancer and antioxidant activity of SPE and its some of photochemical compounds. In this context, anti-proliferative and apoptosis inducing activity of SPE on cervical cancer cell line HeLa was determined. Moreover, levels of IL6 and IL8 levels, which were found to play a role in the pathogenesis of cervical cancer, were determined after SPE application. In addition, antioxidant activities of SPE were determined by DPPH scavenging, DNA protecting and cellular antioxidant activity. Finally, some compounds of SPE were defined by LC-MSMS.

\section{MATERIALS AND METHODS}

\section{Collection of $S$. perfoliata and preparation of SPE}

$S$. perfoliata was collected from Idilli VillageIslahiye-Gaziantep-Turkey and defined by Dr. Mustafa Pehlivan at 05.06,2017 (voucher number: MPH2017-5). S. perfoliata were air dried in a dark room and its aerial parts were pulverized. Then, $40 \mathrm{~g}$ of plant powder was extracted by Soxhlet appratus. For preparation of methanol extracts, this plant material placed into the Soxhlet apparatus was treated with methanol for 6 hours at $50-60^{\circ} \mathrm{C}$. The methanol into the solution was eliminated by using rotary evaporator at $50^{\circ} \mathrm{C}$ and remaining solid material was preserved at $+4^{\circ} \mathrm{C}$ until use.

\section{Determination of DPPH scavenging activity}

DPPH scavenging activity of SPE was tested according to the method applied by Saint-Cricq de Gaulejac et al. (1999). $0.1 \mathrm{~mL}$ of SPE doses was mixed to $2.9 \mathrm{~mL}$ of solution of DPPH and then the mixed solution has been saved in the dark for $45 \mathrm{~min}$. $300 \mu \mathrm{L}$ of the solution was taken and added to the 96 well plates, and it was measured at $517 \mathrm{~nm}$ in a colorimetric reader (Biochrom, UK).

\section{DNA protecting activity of SPE against the hydroxyl radical}

DNA protecting activity of SPE was detected by using plasmid DNA pBR322. Standard solutions were prepared at $25,50,100$, and $200 \mu \mathrm{g} / \mathrm{mL}$ doses of SPE. At first, $0.5 \mu \mathrm{g}$ of pBR322 was put in the Eppendorf tubes, then, $10 \mu \mathrm{L}$ of the standard solutions of SPE were added to it. Also, $10 \mu \mathrm{L}$ of Fenton's agent $\left(30 \mathrm{mM} \mathrm{H} \mathrm{O}_{2}, 50 \mu \mathrm{M}\right.$ ascorbic acid, and $80 \mu \mathrm{M} \mathrm{FeCl}_{3}$ ) was added into the prepared solution and incubated at the room temperature for 10 minutes. The final volume was prepared to be $20 \mathrm{ml}$ 
and allowed to stay for 30 minutes at $37^{\circ} \mathrm{C}$. Then, pBR322 DNA was performed by electrophoresis on $1 \%$ agarose gel (Lee et al., 2002)

\section{Determination of Cellular antioxidant activity (CAA)}

CAA of SPE in HeLa cells was assessed according to method of Wolfe et al. (2008). Briefly, cells were dispersed to 96-well plates with a density of $6 \times 10^{4}$ per milliliter and incubated for a period of $24 \mathrm{~h}$. Later, growth medium was removed and cells were washed with PBS. Then wells were incubated with the $25 \mu \mathrm{M}$ of $2^{\prime}, 7^{\prime}$-dichlorofluorescin diacetate (DCFH-DA) and $100 \mu$ of SPE doses for 1 hour. Subsequently, wells were washed with $100 \mu \mathrm{L}$ of PBS solution and $600 \mu \mathrm{M}$ of 2,2'-azobis(2-ethylpropionamidine) dihydrochloride (ABAP) were added. Results were read at emission $538 \mathrm{~nm}$ and excitation $485 \mathrm{~nm}$ wavelengths every 5 minutes for 1 hour in florescence spectrophotometer (Termo, Germany).

Determination of Cell Viability by MTT (3- [4,5dimethylthiazol- 2- yl]- 2,5- diphenyl- tetrazolium bromide)

HeLa cells were cultured in 96-well plates and complete growth medium with FCS was replaced with serum free (SF) medium after cells reached 70$80 \%$ confluence and incubated with 24 hours. Subsequently, HeLa cells were incubated with 25,50 , 100 and $200 \mu \mathrm{g} / \mathrm{mL}$ doses of SPE for 24 hours. As a positive control, cells were grown in the presence of $10 \%$ FCS were used. Cell viability was evaluated by using MTT staining method. Culture medium was replaced with SF medium containing $1 \mathrm{mg} / \mathrm{mL}$ MTT (Sigma) and incubated at $37^{\circ} \mathrm{C}$ for $15 \mathrm{~min}$. MTT was further removed and blue formazan crystals were dissolved by using DMSO (Sigma). The color change was read at $550 \mathrm{~nm}$ with a colorimetric reader (Biochrom, UK).

\section{Determination of Apoptosis Induction}

To determine the induction of apoptosis, HeLa cells were seeded with a $1 \times 10^{6} / \mathrm{mL}$ density to 6-well plates, and 25, 50, 100 and $200 \mu \mathrm{g} / \mathrm{mL}$ doses of SPE was applied for a period of 24 hours. Annexin V/PI (Becton Dickinson, Pharmingen, UK) apoptosis detection kit was used to measure cellular apoptosis and manufacturer' recommended protocols were followed. Results were measured in BectonDickinson FACSort flow cytometer.

\section{Determination of IL6 and IL8 levels}

HeLa cells were incubated for 24 hours after SPE application. Then, supernatants in wells were taken and interleukin 6 (IL6) and Interleukin 8 (IL8) levels were determined by the Elisa kits according to the protocol of manufacturer.

\section{Determination of phenolic compounds by $L C-M S$ - MS}

Samples for phytochemical analysis of SPE were prepared by dissolving samples in methanol and then filtrated with $0.22 \mu \mathrm{M}$ filter. The LC-MS-MS apparatus of Nexera UHPLC (Shimadzu) with LC20AD two pumps, DGU-20A3R degasser, CTO10ASVP column furnace and SIL-20AC autosampler was used for the study. C18 Intersil ODS-4 analytical colon $(3.0 \mathrm{~mm} \times 100 \mathrm{~mm}, 2 \mu \mathrm{m})$ was used. The injection volume was $2 \mu \mathrm{L}$ and flow rate $0.3 \mathrm{ml} / \mathrm{min}$. Mobile phase A (Water and $0.1 \%$ Formic acid) and mobile phase B (Methanol and $0.1 \%$ Formic acid) were used in a linear gradient flow and column temperature was set at $40^{\circ} \mathrm{C}$ initially.

\section{Statistical Analysis}

SPSS 15.0 program was used the statistical analyses. DPPH, MTT, and IL6 and IL8 were evaluated by one-way analysis of variance (ANOVA). Dunnett test were used to compare the doses applied with controls. Tukey's pair-wise multiple comparison test was used to determine the differences between the groups of significant variables. The results were pointed out as mean $\pm \mathrm{SD}$. The level of significance was accepted to be at least $p<0.05$.

\section{RESULTS}

Determination of DPPH scavenging activity of SPE $\mathrm{DPPH}$, which is a cationic free radical, is purple when dissolved in methanol and if there is an antioxidant in the environment, the reaction color turns from purple to yellow. Tukey HSD test of One Way Anova was used to determine statistically significance differences between the groups. Figure No. 1 shows the DPPH scavenging activity of SPE. It could be seen that the $2 \mathrm{mg} / \mathrm{mL}$ dose of SPE neutralized $43 \%$ of DPPH $(p<0.05)$. The doses of 25 , 50 and $100 \mu \mathrm{g} / \mathrm{mL}$ of SPE exhibited weak radical scavenging activity. Ascorbic acid was used as a positive control in this assay and all its doses exhibited high antioxidant activity $(p<0.05)$, excepting $0.25 \mu \mathrm{g} / \mathrm{mL}$ dose $(p>0.05)$. It was found the SPE exhibited a weaker DPPH scavenging activity when compared to ascorbic acid. 


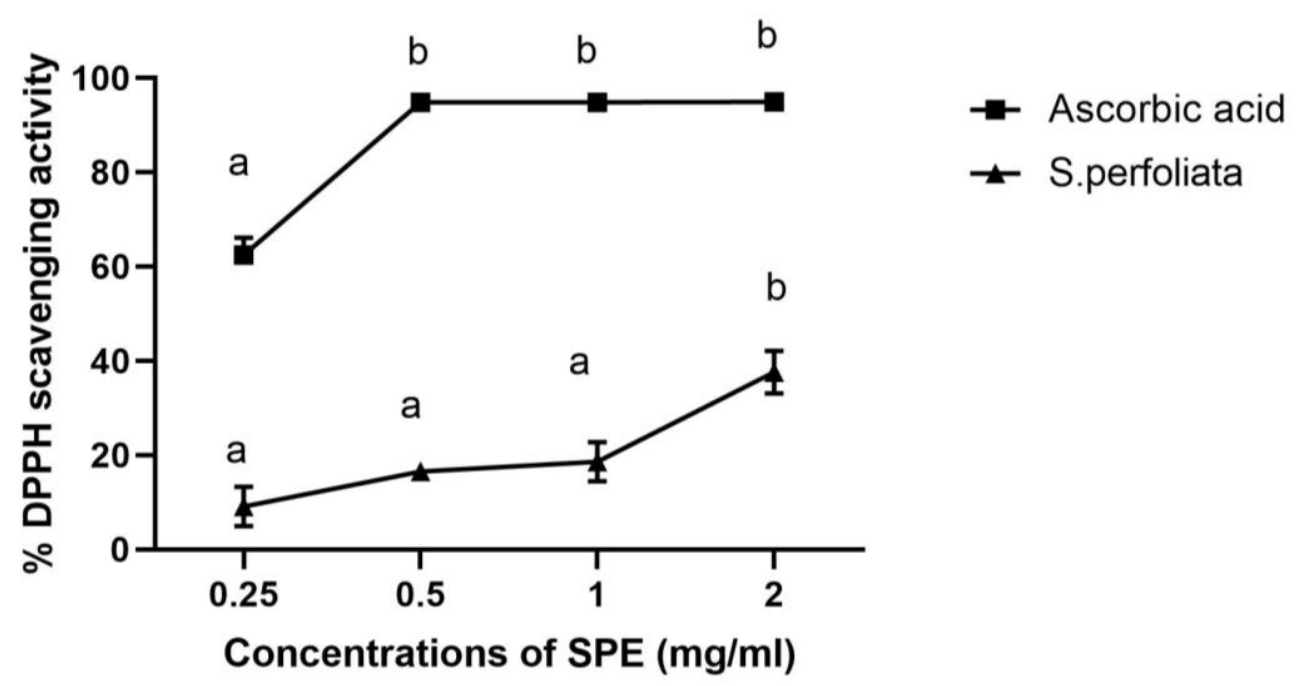

Figure No. 1

DPPH scavenging activities of SPE doses. Tukey HSD test was used to determine statistically significance differences between the groups. Means different letters on the same line are significantly different $(p<0.05)$

Determination of DNA protection activity of SPE against to hydroxyl radical

In DNA protection activity, it was evaluated the transformation of pBR322 DNA exposed to hydroxyl radical after SPE application. When pBR322 is exposed to hydroxyl radical, the double DNA chain (form I) loosens and transforms from supercoiled structure to linear form (form II) or damaged DNA form (form III) (Burrows \& Muller, 1998). The effects of $25,50,100$ and $200 \mu \mathrm{g} / \mathrm{mL}$ of SPE on pBR322 DNA exposed to the hydroxyl radical were shown in Figure No. 2. As illustrated Figure No. 2, while none of SPE protected transformation of DNA from form I to form III, they showed DNA protecting activity at transformation from form II to form III.

\section{Determination of Cellular antioxidant activity} (CAA) of SPE on HeLa

CAA activity is used to measure the antioxidant capacity of a compound to prevent peroxyl radical (Wolfe \& Liu, 2007). In present study, CAA was determined by measuring the peroxyl radical levels in HeLa cancer cells after SPE application. Fluorescence level of the reaction was measured at every 5 minutes during 1 hour after SPE application. It was determined that $200 \mu \mathrm{g} / \mathrm{mL}$ dose of SPE exhibited higher CAA than 25,50 and $100 \mu \mathrm{g} / \mathrm{mL}$ doses of SPE (Figure No. 3), exhibited similar and low CAA.

Determination of Anti-proliferative Activity of SPE on HeLA cells

Antiproliferative effects of 25, 50, 100 and 200 $\mu \mathrm{g} / \mathrm{mL}$ doses of SPE were tested by using MTT staining method on HeLa cells and results were given in Figure No. 4. Dunnett test was used to determine statistically significance differences between the groups. It was determined that SPE inhibited the proliferation of cancer cells in a dose dependent manner. As illustrated Figure No. 4, $200 \mu \mathrm{g} / \mathrm{mL}$ dose of SPE showed the strongest anti-proliferation activity on cancer cells when compared to control DMSO ( $p<0.001)$. Moreover, 50 and $100 \mu \mathrm{g} / \mathrm{mL}$ doses showed an approximate anti-proliferative effect to the effect of $200 \mu \mathrm{g} / \mathrm{mL}$ dose $(p<0.01)$. Only 25 $\mu \mathrm{g} / \mathrm{mL}$ dose exhibited a moderately anti-proliferative effect when compared to other doses $(p<0.05)$. 


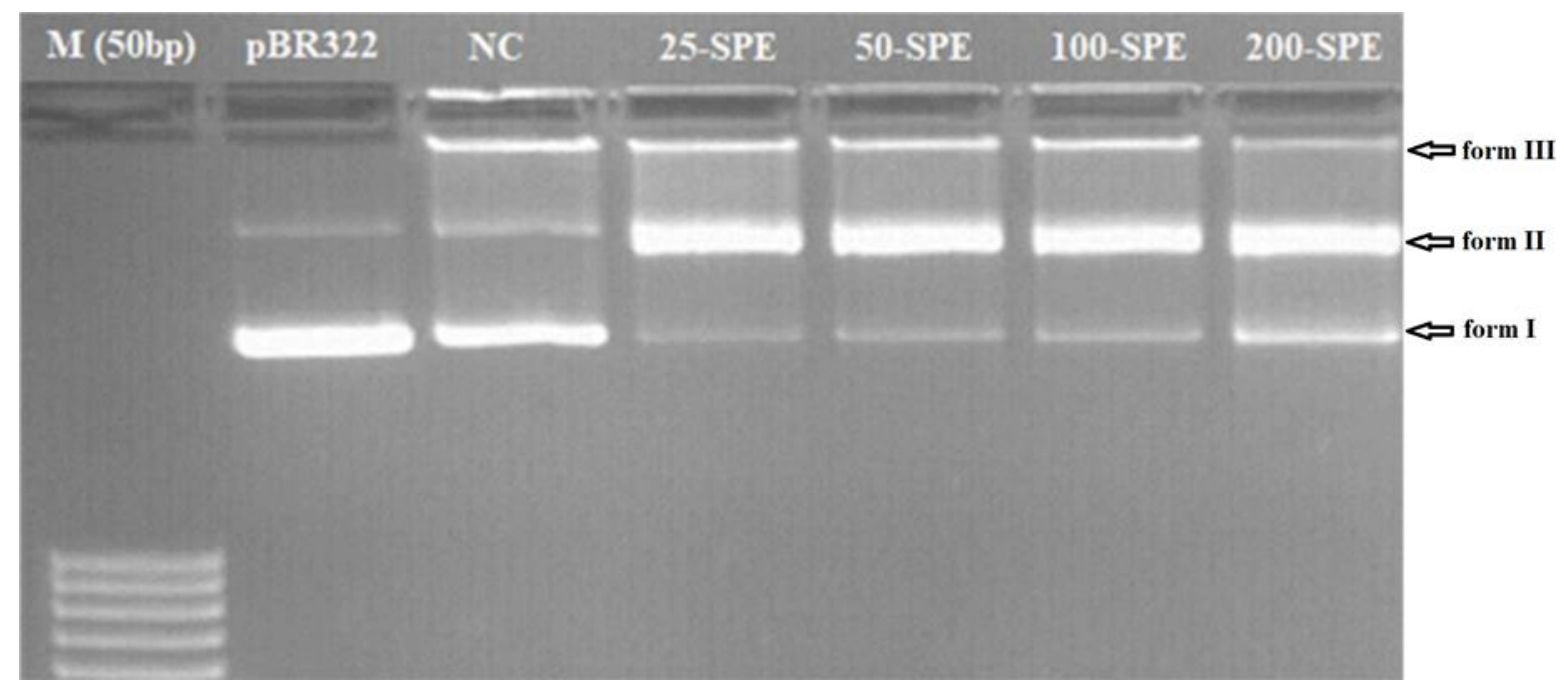

Figure No. 2

DNA protecting activities of SPE doses against the hydroxyl radical. Form I: Supercoiled DNA, Form II: Linear DNA, Form III: Nicked DNA, M: marker, NC: Negative control

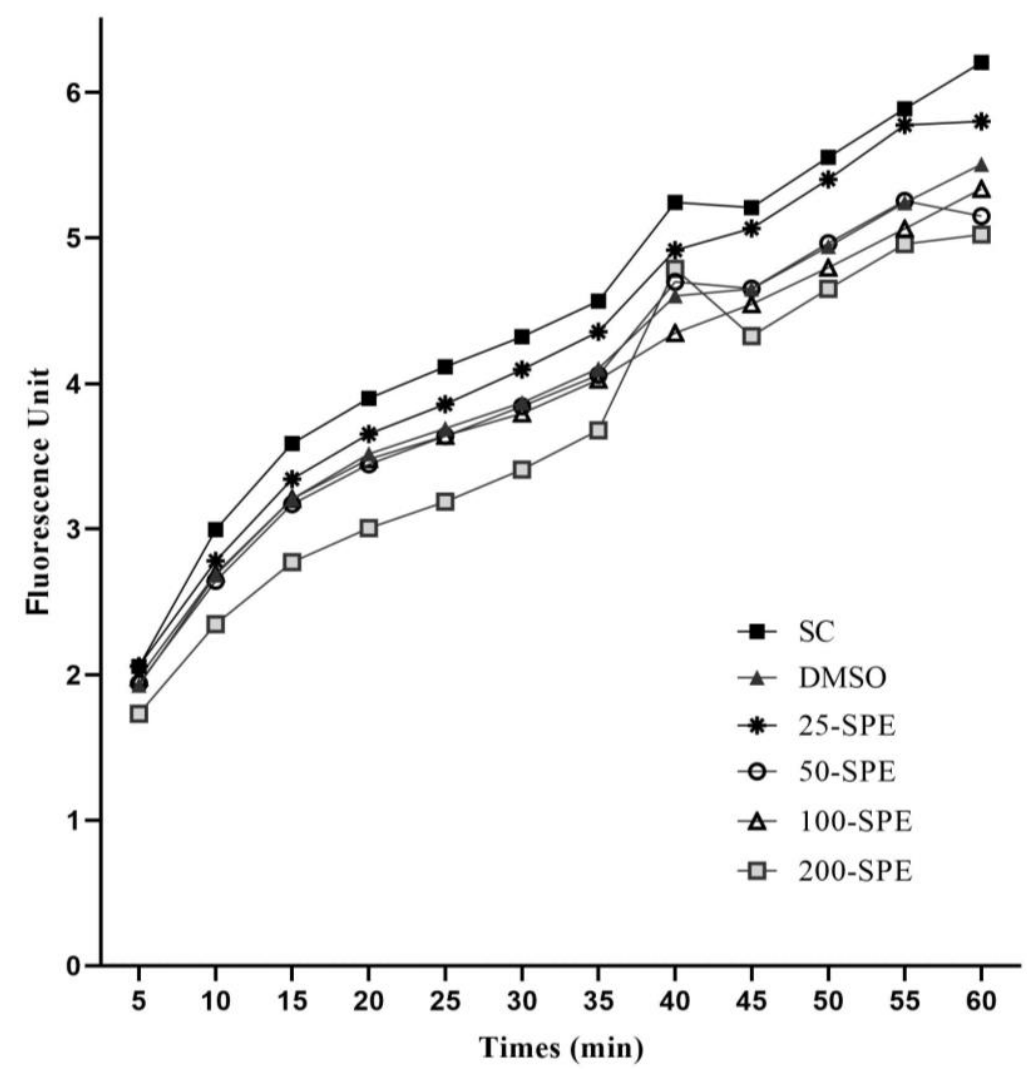

Figure No. 3

CAA of SPE doses on HeLa cells. SC: Saline control, DMSO: Dimethyl sulfoxide control 


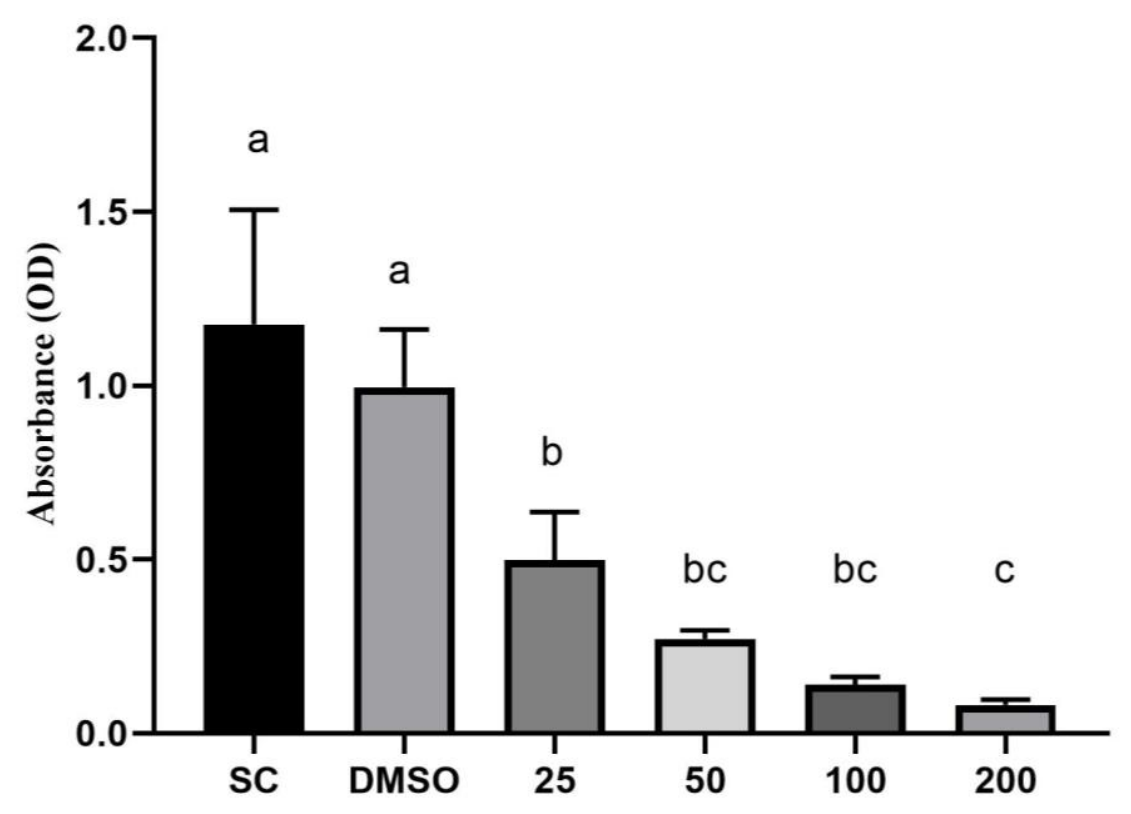

Concentrations of $\mathrm{S}$. perfoliata $(\mu \mathrm{g} / \mathrm{ml})$

Figure No. 4

Antiproliferative effects of SPE doses on HeLa cells. SC: Saline control, DMSO: Dimethyl sulfoxide control. Dunnett test was used to determine statistically significance differences between the groups and control. Means different letters on the different columns are significantly different $(p<0.001)$

Determination of Apoptosis Induction in HeLa Cancer Cells after the SPE Application

To determine the percentage rates of apoptotic phases induced in HeLa cells were used to the lowest (25 $\mu \mathrm{g} / \mathrm{mL})$ and highest $(200 \mu \mathrm{g} / \mathrm{mL})$ doses of SPE. Results of apoptosis induction were given in Figure No. 5. It was determined that while the rate of early apoptotic cells were $29.36 \%$ in control DMSO group after 24 hours of applying of SPE doses, those of 25 and $200 \mu \mathrm{g} / \mathrm{mL}$ SPE doses were $34.66 \%$ and $36.20 \%$, respectively. Moreover, both doses of SPE also increased rate of late apoptotic (22.9 and 25.9\%, respectively) cell when compared to the control group $(21.9 \%)$. It was also found that necrotic cell count was less than $1 \%$ in all groups.

Determination of IL6 and IL8 levels after the SPE Application

After applying of SPE, the supernatants of HeLa cells in wells were taken and their levels of IL6 and IL8 were measured by ELISA method. Dunnett test was used to determine statistically significance differences between the groups and control. The results were given in Figure No. 6. As shown Figure No. 6, while the $25(591.85 \mathrm{pg} / \mathrm{mL}), 50(806.31$ $\mathrm{pg} / \mathrm{mL})$ and $100(1530.92 \mathrm{pg} / \mathrm{mL}) \mu \mathrm{g} / \mathrm{mL}$ doses of SPE increased the level of IL-6 in HeLa cell when compared to control DMSO $(379.75 \mathrm{pg} / \mathrm{mL})$, the 200 $(91.65 \mathrm{pg} / \mathrm{mL}) \mu \mathrm{g} / \mathrm{mL}$ dose of SPE significantly decreased the levels of IL8 when compared to control DMSO and other SPE doses $(p<0.05)$. it was also found that the levels of IL8 increased significantly with applying of the $25(367.87 \mathrm{pg} / \mathrm{mL}), 50(499.53$ $\mathrm{pg} / \mathrm{mL})$ and $100(1800.28 \mathrm{pg} / \mathrm{mL}) \mu \mathrm{g} / \mathrm{ml}$ doses when compared to control DMSO (196.27 pg/mL) $(p<0.05)$. Interestingly, as similar to results of IL-6, $200 \quad(91.65 \quad \mathrm{pg} / \mathrm{mL}) \quad \mu \mathrm{g} / \mathrm{ml}$ dose significantly decreased the levels of IL8 when compared to control DMSO and other SPE doses $(p<0.05)$. 


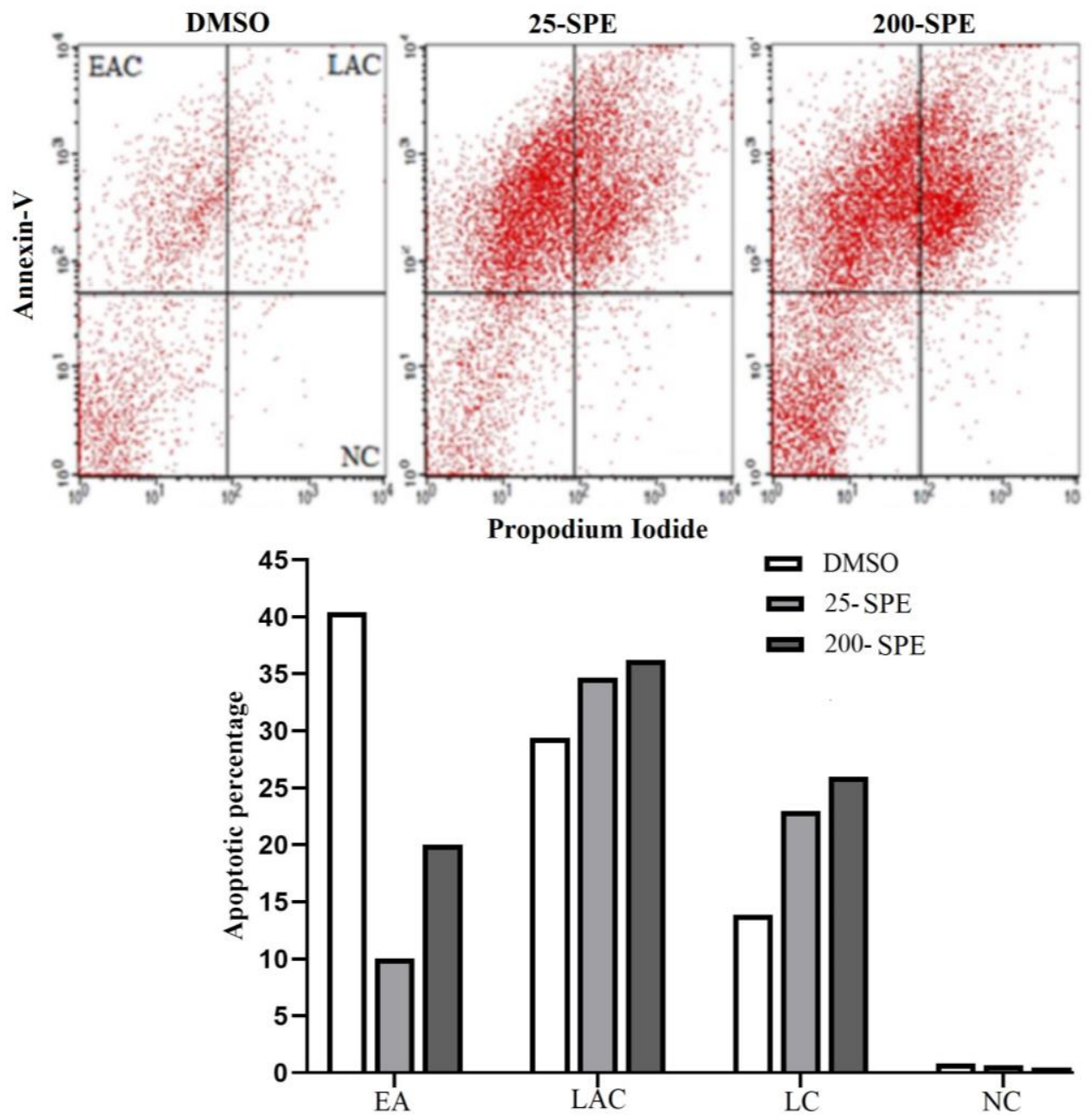

Figure No. 5

Percentages of the early and late apoptotic HeLa cancer cells after SPE application. LC: Living cells, EAC: Early apoptotic cells, LAC: Late apoptotic cells, NC: Necrotic cells

Determination of phytochemical of SPE by LC-MS$M S$

SPE were screened by LC-MS-MS for its phytochemicals. The substances defined and their quantities were given in Figure No. 7. The nine compounds were identified in SPE. While vanillic acid and hydroxycinnamic acid were determined as the highest amounts (961.03 and $185.91 \mu \mathrm{g} / \mathrm{mL}$, respectively), quercetin and acetohydroxycinnamic acid was the least $(0.89$ and $1.35 \mu \mathrm{g} / \mathrm{mL}$, respectively).

\section{DISCUSSION}

There are many studies about the antioxidant activities of Sideritis species in previous studies. Erkan et al. (2011), reported to have the DPPH scavenging activity of methanol, ethanol and ethyl acetate extracts of $S$. congesta and $S$. arguta. In another study, especially the polar extracts of $S$. galatica have been reported to exhibit a strong DPPH scavenging activity (Zengin et al., 2014). In the present study, the SPE moderately exhibited DPPH scavenging activity in a doses dependent manner. Moreover, only DPPH may not be sufficient to assess the antioxidant activity. Hence, in other antioxidant test system we studied the DNA protective activity of SPE against hydroxyl radical. The free radicals exhibit destructive effects on nucleic acids in cells. 


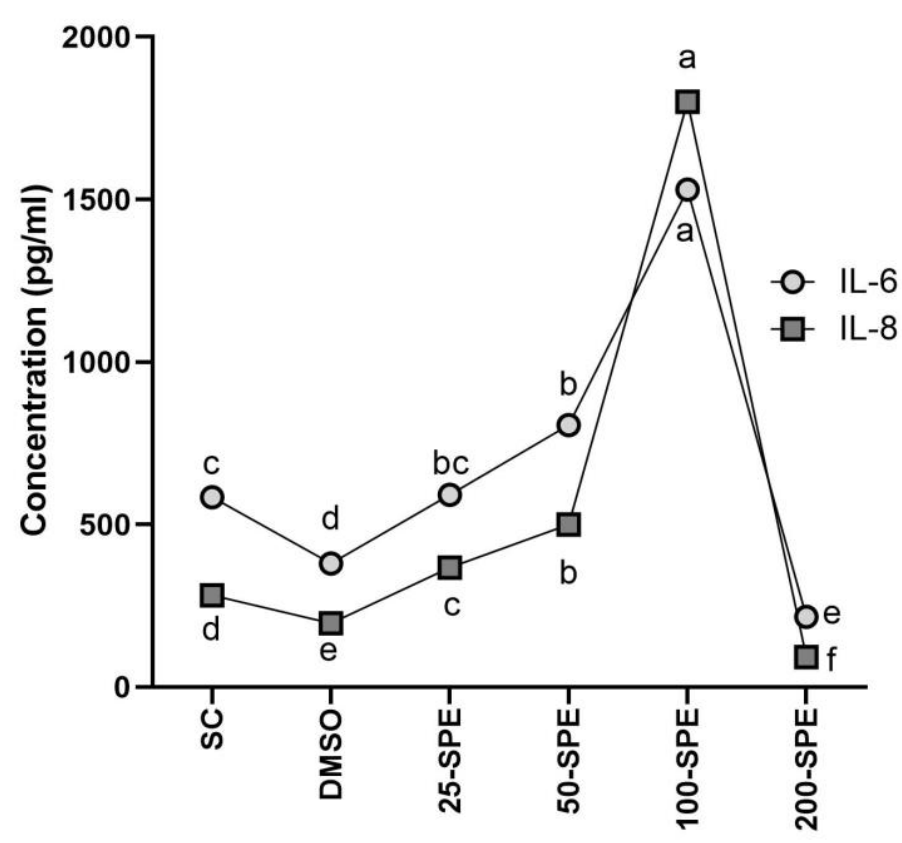

Figure No. 6

IL-6 and IL-8 levels on HeLa cells after SPE application. SC: Saline control, DMSO: Dimethyl sulfoxide control. Dunnett test was used to determine statistically significance differences between the groups and control. Means different letters on the same line are significantly different $(p<0.01)$

These radicals attach to the sugar-phosphate backbone on DNA and cause to break down of DNA (von Sonntag, 1987). The DNA protecting activity of extracts and essential oils from some plants belonging to Lamiaceae against free radicals has been shown in previous studies (Yumrutas \& Saygideğer, 2010; Yumrutas et al., 2012). In present study, however, the all of the doses of SPE showed a weak DNA protective activity against the hydroxyl radical. In addition to the antioxidant activities of extracts or natural compounds in in vitro test systems, to determine their antioxidant activities in the living cells is also necessary for a more precise evaluation. If an antioxidant molecule reacts directly with ROO or indirectly with ROS, the oxidation of $\mathrm{DFCH} 2$ is inhibited, and therefore the level of fluorescence reduces in the cellular antioxidant activity system. In the present study, while 25,50 and $100 \mu \mathrm{g} / \mathrm{mL}$ doses of SPE showed a weak CAA, only $200 \mu \mathrm{g} / \mathrm{mL}$ dose showed a moderate antioxidant activity. These results were similar to the results of DPPH scavenging activity in this study. When the results of DPPH and CAA, excepting DNA protection activity, were evaluated, it was considered that high doses of SPE might exhibit the antioxidant activity.

Besides the antioxidant activities of SPE, its anticancer potential was determined in the present study. At first it was demonstrated that SPE prevent the viability and proliferation of HeLa cells in a dose dependent manner. Previous studies have reported the anti-proliferative effects of Sideritis species on different cancer cells. S. libanotica ssp. linearis has been reported to have the antiproliferative effect on HeLa cells (Demirtas et al., 2009). In another study, it has shown that $S$. floridana inhibits the proliferation and growth of human colon cancer HT29 cell line (Ma et al., 2013). In the present study, it can be said that especially high doses of SPE have a strong anti-proliferative effect on HeLa cancer cells. Only anti-proliferation test, however, is not enough to show whether a substance has anticancer activity or not, and additional tests such as induction of apoptosis, which is which is programmed cell death, is one of the most important pathways used to destroy a cancer cell (Johnstone et al., 2002), are required. Hence, in the present study it was determined the induction of apoptosis in HeLa cells after SPE application, and the high dose of SPE 
increased the induction of apoptosis. As a result of our literature survey, it can be said that this study is the first report showing the apoptosis inducing effect of $S$. perfoliata in cervical cancer cells. Moreover, there are studies showing the apoptotic effects of different Sideritis species in the literature. In a previous study, it has reported that $S$. öztürkii induce apoptosis by increasing of expressions of APAF, BAX, P53 and Caspase3 (apoptotic proteins) and by decreasing of BCL2 (antiapoptotic protein) expression in colorectal cancer cells. Based on the above mentioned, SPE is thought to have an anticancer activity by inducing apoptosis in $\mathrm{HeLa}$ cancer cells. In this study HeLa cells only was exposed to SPE doses for 24 hours, 48 and 72 hours of SPE exposure is thought to further increase the induction of apoptosis.<smiles>O=c1c(O)c(-c2ccc(O)c(O)c2)oc2cc(O)cc(O)c12</smiles>

quercetin $(0.89 \mu \mathrm{g} / \mathrm{ml})$<smiles>Oc1ccc(/C=C/c2cc(O)cc(O)c2)cc1</smiles>

resveratrol $(44.33 \mu \mathrm{g} / \mathrm{ml})$<smiles>O=C(O)/C=C/c1ccc(O)cc1</smiles>

hyrdroxycinnamic acid $(185.91 \mu \mathrm{g} / \mathrm{ml})$

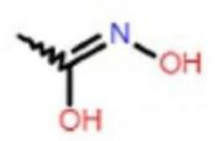

acetohydroxamic acid $(1.35 \mu \mathrm{g} / \mathrm{ml})$

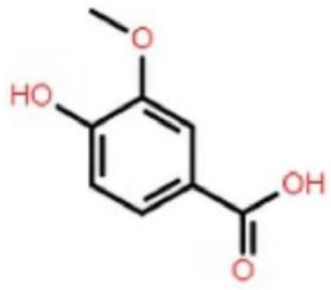

vanillic acid $(961.03 \mu \mathrm{g} / \mathrm{ml})$

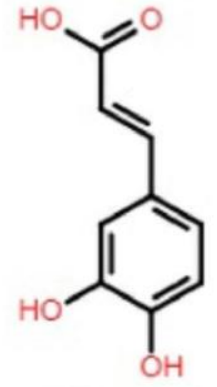

caffeic acid $(3.61 \mu \mathrm{g} / \mathrm{ml})$

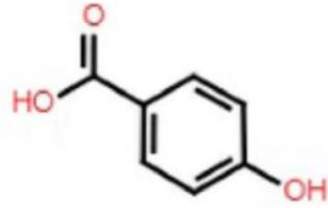<smiles>O=C1c2ccccc2C(=O)c2c1ccc(O)c2O</smiles>

alizarin $(56.53 \mu \mathrm{g} / \mathrm{ml})$<smiles>O=C(O)c1ccccc1O</smiles>

hydroxybenzoic acid $(5.13 \mu \mathrm{g} / \mathrm{ml})$

salicylic acid $(15.81 \mu \mathrm{g} / \mathrm{ml})$

Figure No. 7

The compounds defined in SPE and their amounts 
Formation of cervical cancer is associated with chronic inflammation (Shust et al., 2010), which is a physiological process used naturally to protect tissues against factors such as inflammation, pathogens, xenobiotic and cells damaged (BarajasGomez et al., 2017). This process allows elimination of the cells damaged and creation of a suitable microenvironment (Barajas-Gomez et al., 2017). Despite these positive effects of inflammation, it also can cause some diseases such as cancer. Interleukins (IL) play important roles in inflammation. The levels of interleukins such as IL 6 and IL 8 increase in the pathogenesis of many cancers. IL 6, which is a central pro-inflammatory and multifunctional cytokine, is known to be produced by many cancer cells. In previous studies, it has been reported an increase in level of IL-6 in pathogenesis of cervical cancer (Tjiong et al., 1999; Wei et al., 2001a; Wei et al., 2001b; Abdelwahab et al., 2012). This increase was considered to suppress the apoptosis in cervical cancer (Wei et al., 2001b). Moreover, important roles of IL8 in the pathogenesis of many cancers have also been identified (Xie, 2001). It has been reported that IL8 increase the proliferation, invasion and metastasis of cancer cells (Palena et al., 2012) and it plays a role in the progression of cervical cancer as an angiogenic prognostic factor (Fujimoto et al., 2000). Tjiong et al. (1999) have reported that both IL6 and IL8 levels increased in cervical cancer cells. In the present study, levels of both IL6 and IL8 were determined in HeLa cancer cells and their levels at $200 \mu \mathrm{g} / \mathrm{mL}$ dose of SPE decreased significantly. It was considered that the increase of induction of apoptosis in HeLa cells was due to reducing of IL6 and IL8 levels after SPE application.
Previous studies presented the biological activities of some of plant-based compounds (Parlar \& Arslan, 2019; Ozay et al., 2019; Parlar et al., 2020). Species belonging to Lamiaceae are rich in phytochemicals. In the present study, in the screening performed with LC-MS-MS, nine compounds were defined in SPE. While vanillic and hydroxycinnamic acid had the highest amount in SPE, acetohydroxamic acid and quercetine was the least. In the present study, the anticancer activities of the compounds defined of SPE on HeLa cells were not tested individually. To make a more precise evaluation about anticancer activities of the compounds defined should be necessary to further studies.

\section{CONCLUSION}

As a result, in this study it was demonstrated that $S$. perfoliata has a strong anticancer activity on HeLa cancer cell because of reducing the cell proliferation, inducting the apoptosis and decreasing IL6 and IL8 levels, however, it has weak effects in terms of antioxidant activity. For a more precise evaluation about anticancer activity of $S$. perfoliata, it is considered that effects of $S$. perfoliata and its compounds defined on levels of proapoptotic (BAX, BAK), anti-apoptotic (BCL-2-BCL-XL) and apoptotic (CASPAS3) proteins in further studies should be determined.

\section{ACKNOWLEDGMENTS}

This work was funded by The Scientific Research Council of Gaziantep University with Project number NMYO.YLT.17.01.

\section{REFERENCES}

Abdelwahab SI, Abdul AB, Zain ZNM, Hadi AHA. 2012. Zerumbone inhibits interleukin-6 and induces apoptosis and cell cycle arrest in ovarian and cervical cancer cells. Int Immunopharmacol 12: 594 - 602. https://doi.org/10.1016/j.intimp.2012.01.014

Balusamy SR, Perumalsamy H, Huq MA, Balasubramanian B. 2018. Anti-proliferative activity of Origanum vulgare inhibited lipogenesis and induced mitochondrial mediated apoptosis in human stomach cancer cell lines. Biomed Pharmacother 108: 1835 - 1844. https://doi.org/10.1016/j.biopha.2018.10.028

Barajas-Gomez BA, Rosas-Carrasco O, Morales-Rosales SL, Pedraza-Vázquez, G, González-Puertos VY, JuárezCedillo T, Garcia-Alvarez JA, Lopez-Diazguerrero NE, Damian-Matsumura P, Königsberg M, Luna-López A. 2017. Relationship of inflammatory profile of elderly patients serum and senescence-associated secretory phenotype with human breast cancer cells proliferation: Role of IL6/IL8 ratio. Cytokine 91: 13 29. https://doi.org/10.1016/j.cyto.2016.12.001

Bray F, Ferlay J, Soerjomataram I, Siegel RL, Torre LA, Jemal A. 2018. Global cancer statistics 2018: GLOBOCAN estimates of incidence and mortality worldwide for 36 cancers in 185 countries. Cancer J Clin 68: 394 - 424. https://doi.org/10.3322/caac.21492

Burrows CJ, Muller JG. 1998. Oxidative nucleobase modifications leading to strand scission. Chem Rev 98 : 1109 1152. https://doi.org/10.1021/cr960421s

Boletín Latinoamericano y del Caribe de Plantas Medicinales y Aromáticas/403 
Celep F, Dirmenci T. 2017. Systematic and biogeographic overview of Lamiaceae in Turkey. Nat Volat Essent Oils 4: $14-27$.

Davis PH, Tan K, Mill RR. 1988. Flora of Turkey and The East Aegean Islands (Vol. 10). Edinburgh University Press, Edinburgh, Scotland.

Demirtas I, Sahin A, Ayhan B, Tekin S, Telci I. 2009. Antiproliferative effects of the methanolic extracts of Sideritis libanotica Labill. subsp. linearis. Records Nat Prod 3: 104 - 109.

Erkan N, Cetin H, Ayranc1 E. 2011. Antioxidant activities of Sideritis congesta Davis et Huber-Morath and Sideritis arguta Boiss et Heldr: Identification of free flavonoids and cinnamic acid derivatives. Food Res Int 44: 297 - 303. https://doi.org/10.1016/j.foodres.2010.10.016

Ertaş A, Ozturk M, Boga M, Topçu G. 2009. Antioxidant and anticholinesterase activity evaluation of ent-kaurane diterpenoids from Sideritis arguta. J Nat Prod 72: 500 - 502. https://doi.org/10.1021/np800671p

Fujimoto J, Sakaguchi H, Aoki I, Tamaya T. 2000. Clinical implications of expression of interleukin 8 related to angiogenesis in uterine cervical cancers. Cancer Res 60: 2632 - 2635.

González-Burgos E, Carretero ME, Gómez-Serranillos MP. 2011. Sideritis spp.: Uses, chemical composition and pharmacological activities: A review. J Ethnopharmacol 135: 209 - 225.

https://doi.org/10.1016/j.jep.2011.03.014

Guner A, Ozhatay N, Ekim T, Başer KHC. (Eds). 2000. Flora of Turkey and The East Aegean Islands (Vol. 11, Supplement 2). Edinburgh University Press, Edinburgh, Scotland.

Hernández-Pérez M, Rabanal Gallego RM. 2002. Analgesic and antiinflammatory properties of Sideritis lotsyi var. Mascaensis. Phytother Res 16: 264 - 266. https://doi.org/10.1002/ptr.866

Ijaz S, Akhtar N, Khan MS, Hameed A, Irfan M, Arshad MA, Ali S, Asrar M. 2018. Plant derived anticancer agents: A green approach towards skin cancers. Biomed Pharmacother 103: 1643 - 1651.

https://doi.org/10.1016/j.biopha.2018.04.113

Johnstone RW, Ruefli AA, Lowe SW. 2002. Apoptosis: a link between cancer genetics and chemotherapy. Cell 108: 153 - 164. https://doi.org/10.1016/s0092-8674(02)00625-6

Kim SE, Kim YS, Shin WB, Park JS, Moon SH, Jeon BT, Park PJ. 2018. Induction of caspase-mediated apoptosis using Alnus japonica extracts in AGS human gastric carcinoma cells. J Appl Biomed 16: 198 - 207. https://doi.org/10.1016/j.jab.2018.01.008

Köse EO, Deniz IG, Sarıürkçü C, Aktaş Ö, Yavuz M. 2010. Chemical composition, antimicrobial and antioxidant activities of the essential oils of Sideritis erythrantha Boiss. and Heldr. (var. erythrantha and var. cedretorum PH Davis) endemic in Turkey. Food Chem Toxicol 48: 2960 - 2965.

https://doi.org/10.1016/j.fct.2010.07.033

Küpeli E, Şahin FP, Çalış İ, Yeşilada E, Ezer N. 2007. Phenolic compounds of Sideritis ozturkii and their in vivo anti-inflammatory and antinociceptive activities. J Ethnopharmacol 112: 356 - 360. https://doi.org/10.1016/j.jep.2007.03.017

Lee JC, Kim HR, Kim J, Jang YS. 2002. Antioxidant property of an ethanol extract of the stem of Opuntia ficusindica var. saboten. J Agric Food Chem 50: 6490 - 6496. https://doi.org/10.1021/jf020388c

Ma L, Qin C, Wang M, Gan D, Cao L, Ye H, Zeng X. 2013. Preparation, preliminary characterization and inhibitory effect on human colon cancer HT-29 cells of an acidic polysaccharide fraction from Stachys floridana Schuttl. ex Benth. Food Chem Toxicol 60: 269 - 276. https://doi.org/10.1016/j.fct.2013.07.060

Mammas IN, Zafiropoulos A, Koumantakis E, Sifakis S, Spandidos DA. 2004. Transcriptional activation of H-and N-ras oncogenes in human cervical cancer. Gynecol Oncol 92: 941 - 948.

https://doi.org/10.1016/j.ygyno.2003.11.040

Özay Y, Güzel S, Yumrutaş Ö, Pehlivanoğlu B, Erdoğdu İH, Yildirim Z, Türk BA, Darcan S. 2019. Wound healing effect of kaempferol in diabetic and nondiabetic rats. J Surg Res 233: 284 - 296.

https://doi.org/10.1016/j.jss.2018.08.009

Palena C, Hamilton DH, Fernando RI. 2012. Influence of IL-8 on the epithelial-mesenchymal transition and the tumor microenvironment. Future Oncology 8: 713 - 722. https://doi.org/10.2217/fon.12.59

Parlar A, Arslan SO. 2019. Resveratrol normalizes the deterioration of smooth muscle contractility after intestinal ischemia and reperfusion in rats associated with an antioxidative effect and modulating tumor necrosis factor alpha activity. Ann Vasc Surg 61: 416 - 426. https://doi.org/10.1016/j.avsg.2019.06.027

Parlar A, Arslan S, Cam SA. 2020. Glabridin alleviates inflammation and nociception by reducing cytokine 
production and oxidative stress. Biol Pharmaceut Bull 43: 884 - 897. https://doi.org/10.1248/bpb.b20-00038

Pavithra PS, Mehta A, Verma RS. 2018. Induction of apoptosis by essential oil from P. missionis in skin epidermoid cancer cells. Phytomedicine 50: 184 - 195. https://doi.org/10.1016/j.phymed.2017.11.004

Pudziuvelyte L., Stankevicius M, Maruska A, Petrikaite V, Ragazinskiene O, Draksiene G, Bernatoniene J. 2017. Chemical composition and anticancer activity of Elsholtzia ciliata essential oils and extracts prepared by different methods. Ind Crops Prod 107: 90 - 96. https://doi.org/10.1016/j.indcrop.2017.05.040

Ramos IELS, Sosa LN, de Paz PLP. 1994. A palynological study of the genus Sideritis subgenus Marrubiastrum (Lamiaceae): Macaronesian endemism. Grana 33: 21 - 37. https://doi.org/10.1080/00173139409427453

Saint-Cricq de Gaulejac N, Provost C, Vivas N. 1999. Comparative study of polyphenol scavenging activities assessed by different methods. J Agric Food Chem 47: 425 - 431. https://doi.org/10.1021/jf980700b

Shakeri A, Delavari S, Ebrahimi SN, Asili J, Emami SA, Tayarani-Najaran Z. 2019. A new tricyclic abietane diterpenoid from Salvia chloroleuca and evaluation of cytotoxic and apoptotic activities. Rev Bras Farmacogn 29: 30 - 35. https://doi.org/10.1016/j.bjp.2018.09.007

Shust GF, Cho S, Kim M, Madan RP, Guzman EM, Pollack, M., Epstein J, Cohen HW, Keller MJ, Herold BC. 2010. Female genital tract secretions inhibit herpes simplex virus infection: correlation with soluble mucosal immune mediators and impact of hormonal contraception. Am J Reprod Immunol 63: 110 - 119.

Smith JS, Herrero R, Bosetti C, Munoz N, Bosch FX, Eluf-Neto J, Castellsague X, Meijer CJLM, Van den Brule AJC, Ashley, R. 2002. Herpes simplex virus-2 as a human papillomavirus cofactor in the etiology of invasive cervical cancer. J Nat Cancer Inst 94: 1604 - 1613. https://doi.org/10.1093/jnci/94.21.1604

von Sonntag C. 1987. The chemical basis of radiation biology. Taylor \& Francis, London, UK.

Tjiong MY, van der Vange N, ten Kate FJ, Tjong-A-Hung SP, ter Schegget J, Burger MP, Out TA. 1999. Increased IL-6 and IL-8 levels in cervicovaginal secretions of patients with cervical cancer. Gynecol Oncol 73: 285 291. https://doi.org/10.1006/gyno.1999.5358

Waugh DJ, Wilson C. 2008. The interleukin-8 pathway in cancer. Clin Cancer Res 14: 6735 - 6741.

Wei LH, Kuo ML, Chen CA, Cheng WF, Cheng SP, Hsieh FJ, Hsieh CY 2001a. Interleukin-6 in cervical cancer: the relationship with vascular endothelial growth factor. Gynecol Oncol 82: 49 - 56. https://doi.org/10.1006/gyno.2001.6235

Wei LH, Kuo ML, Chen CA, Chou CH, Cheng WF, Chang MC, Su JL, Hsieh, CY. 2001b. The anti-apoptotic role of interleukin-6 in human cervical cancer is mediated by up-regulation of Mcl-1 through a PI 3-K/Akt pathway. Oncogene 20: 5799 - 5809. https://doi.org/10.1038/sj.onc.1204733

WHO, 2018. Cancer. URL https://www.who.int/health-topics/cancer\#tab=tab_1

Wolfe KL, Liu RH. 2007. Cellular antioxidant activity (CAA) assay for assessing antioxidants, foods, and dietary supplements. J Agric Food Chem 55: 8896 - 8907. https://doi.org/10.1021/jf0715166

Wolfe KL, Kang X, He X, Dong M, Zhang Q, Liu RH. 2008. Cellular antioxidant activity of common fruits. J Agric Food Chem 56: 8418 - 8426. https://doi.org/10.1021/jf801381y

Xie K. 2001. Interleukin-8 and human cancer biology. Cytokine Growth Factor Rev 12: 375 - 391.

Yumrutas O, Saygideger SD. 2010. Determination of in vitro antioxidant activities of different extracts of Marrubium parviflorum Fish et Mey. and Lamium amplexicaule L. from South east of Turkey. J Med Plants Res 4: 2164 - 2172.

Yumrutas O, Sokmen A, Akpulat HA, Ozturk N, Daferera D, Sokmen M, Tepe B. 2012. Phenolic acid contents, essential oil compositions and antioxidant activities of two varieties of Salvia euphratica from Turkey. Nat Prod Res 26: 1848 - 1851. https://doi.org/10.1080/14786419.2011.613386

Zengin G, Sarikurkcu C, Aktumsek A, Ceylan R. 2014. Sideritis galatica Bornm.: A source of multifunctional agents for the management of oxidative damage, Alzheimer's and diabetes mellitus. J Funct Foods 11: 538 - 547. https://doi.org/10.1016/j.jff.2014.08.011 